\title{
Ulasan Buku "Struggling for Air: Power Plants and The War on Coal" oleh Richard L. Revesz dan Jack Lienke
}

Fajri Fadhillah ${ }^{1}$

$\begin{array}{ll}\text { Penulis } & \text { : Richard L. Revesz } \\ & \text { Jack Lienke } \\ \text { Judul Buku } & : \text { Struggling for Air } \\ & \text { Power Plants and the "War on Coal" } \\ \text { Penerbit } & : \text { Oxford University Press } \\ \text { Kota terbit } & : \text { New York } \\ \text { Waktu terbit } & : \text { Edisi pertama tahun } 2016 \\ \text { Jumlah halaman } & : \text { 231 halaman (termasuk } 10 \text { halaman dengan huruf romawi) } \\ \text { ISBN } & : 978-0-19-023311-2\end{array}$

Buku berjudul "Struggling for Air: Power Plants and the "War on Coal" menjelaskan tentang ketentuan "grandfathering", yakni kelemahan dari 1970 Clean Air Act yang memberikan kewenangan pemerintahan federal Amerika Serikat untuk menetapkan baku mutu emisi yang lebih ketat untuk Pembangkit Listrik Tenaga Uap berbahan bakar batubara (PLTU Batubara) baru, namun mengecualikan baku mutu emisi tersebut untuk PLTU Batubara yang sudah lebih dulu beroperasi. Ketentuan tersebut menyebabkan upaya pemulihan udara di negara-negara bagian di Amerika Serikat semakin sulit karena PLTU-PLTU batubara tua dengan emisi yang tinggi tetap beroperasi bahkan melebihi umur operasi pada umumnya. Ulasan buku ini menjadi relevan diletakkan dalam kon- teks upaya pengendalian pencemaran udara di Indonesia yang juga didominasi oleh PLTU Batubara dalam sistem ketenagalistrikannya.

Struggling for Air merupakan hasil karya Richard L. Revesz dan Jack Lienke. Richard L. Revesz merupakan ahli terkemuka di bidang kebijakan dan hukum lingkungan dari Amerika Serikat. Revesz adalah profesor hukum dan mantan dekan di New York University School of Law, di mana kini Revesz menjadi Direktur di Institute for Policy Integrity. Jack Lienke merupakan pengacara senior di Institute for Policy Integrity. Lienke fokus pada topik mengenai kebijakan perubahan iklim dan pengaturan di bidang lingkungan hidup lainnya.

\footnotetext{
${ }^{1}$ Penulis adalah Peneliti Divisi Pengendalian Pencemaran pada Indonesian Center for Environmental Law
} 
Struggling for Air merupakan buku yang ketika kita selesai membacanya, kita akan memahami kesulitan-kesulitan yang dihadapi untuk mengendalikan emisi dari PLTU Batubara. Sebelum menguraikan kesulitan-kesulitan tersebut, Revesz dan Lienke memberikan penjelasan ringkas mengenai batubara, mencakup apa itu batubara, di mana dan bagaimana kita memanfaatkan batubara, serta dampak-dampak negatif yang timbul akibat pemanfaatan batubara terhadap lingkungan hidup. Pembaca yang belum pernah menggali lebih detail mengenai batubara jadi cukup mengerti dengan penjelasan ringkas tersebut.

Sebelum masuk ke inti permasalahan, Revesz dan Lienke dengan baik menggugah minat pembaca terlebih dahulu dengan memberikan konteks bagi pembaca, yakni: munculnya retorika mengenai "Perang terhadap Batubara" yang dilancarkan terhadap Presiden Barack Obama selama dua periode kepresidenannya. Pembaca diajak terlebih dahulu mengetahui konteks ketika Obama dicap sebagai Presiden yang anti batubara karena menerbitkan 3 (tiga) peraturan yang bertujuan mengurangi emisi dari PLTU batubara di Amerika Serikat, yakni: The Cross-State Air Pollution Rule, The Mercury and Air Toxics Standards dan The Clean Power Plan. Dari konteks ini, Revesz dan Lienke menekankan pentingnya konteks historis dalam melihat suatu cerita. Konteks historis ini menunjukkan upaya mengendalikan emisi dari PLTU nyatanya sudah berlangsung sejak 4 (empat) dekade sebelum periode kepresidenan Obama. Upaya pengendalian ini sudah dilakukan tidak hanya dalam periode kepresidenan dari kubu Demokrat, tapi juga kubu Republik.

Revesz dan Lienke menulis secara kronologis dan analitis ketika menjelaskan upaya pengendalian emisi dari PLTU Batubara di Amerika Serikat. Mereka berdua mundur ke belakang hingga periode akhir tahun 1960an sampai tahun 1970, di mana regulasi utama mengenai pengendalian pencemaran udara, 1970 Clean Air Act disahkan. Mereka menggali transkrip dan diskursus publik yang muncul pada periode waktu tersebut untuk melihat latar belakang munculnya ketentuan "Grandfathering" dalam 1970 Clean Air Act. Rasionalitas adanya ketentuan Grandfathering juga diuraikan dan dikomentari.

Setelah menjelaskan latar belakang munculnya ketentuan "Grandfathering" dalam 1970 Clean Air Act, Revesz dan Lienke memulai analisisnya mengenai masalah-masalah yang muncul akibat ketentuan "Grandfathering" tersebut. Masalah pertama adalah sulitnya mengimplementasikan ketentuan modifikasi dalam 1970 Clean Air Act, yakni ketentuan yang memerintahkan pemberlakuan baku mutu emisi yang lebih ketat kepada PLTU yang sudah beroperasi setiap ada modifikasi dalam PLTU tersebut. 
Masalah kedua adalah soal dampak kesehatan yang timbul akibat emisi yang tinggi dari PLTU-PLTU tua. Dampak kesehatan tersebut semakin kompleks karena pencemaran udara dari PLTU bersifat lintas batas negara bagian. Masalah yang terakhir adalah upaya pengusaha PLTU-PLTU tua untuk membatalkan penyusunan peraturan yang bertujuan untuk mengurangi emisi gas rumah kaca di Amerika Serikat.

Revesz dan Lienke menutup bukunya dengan harapan: kebijakan pengendalian emisi dari Obama dan rendahnya harga energi dari gas memberikan peluang untuk penutupan PLTU-PLTU tua yang sudah terlalu lama mencemari udara Amerika Serikat.

Struggling for Air berhasil menunjukan pentingnya konteks sejarah dalam memahami suatu peristiwa di masa kini. Revesz dan Lienke dengan sangat baik menunjukan bahwa perbedaan periode waktu akan menghasilkan pemaknaan yang berbeda dalam melihat suatu narasi. Narasi “Obama memulai perang terhadap batubara" terasa nyata apabila kita memahaminya hanya terbatas pada periode waktu masa kepresidenannya. Revesz dan Lienke, dengan menekankan pada pentingnya konteks sejarah, berhasil meruntuhkan narasi tersebut dengan menjelaskan cukup detail upaya pengendalian emisi PLTU Batubara sejak periode akhir dekade 1960 hingga periode terkini. Penekanan konteks histori ini berguna dalam menelaah narasi-narasi lainnya yang berkembang di publik.

Struggling for Air juga memberikan petunjuk-petunjuk yang bermanfaat bagi negara-negara yang sedang bergelut dengan upaya pengendalian emisi dari PLTU Batubara. Dua tahun belakangan ini, Kementerian Lingkungan Hidup dan Kehutanan (KLHK) menjalankan proses perubahan baku mutu emisi untuk PLTU Batubara. KLHK harus lebih cermat dalam merancang perubahan baku mutu emisi tersebut agar PLTU-PLTU batubara yang tua tidak mendapatkan keistimewaan berupa baku mutu emisi yang sangat longgar. Struggling for Air menunjukkan keistimewaan seperti itu menimbulkan masalah besar: PLTUPLTU batubara yang tua terus beroperasi dengan emisi yang tinggi.

Pada akhirnya, saya merekomendasikan Struggling for Air sebagai bacaan penting bagi siapa pun di luar sana yang tertarik dengan cerita tentang perjalanan menuju perubahan. Hal-hal teknis yang terkesan rumit dalam bisnis PLTU Batubara disampaikan dengan menarik oleh Revesz dan Lienke. Jadi, buku ini tidak eksklusif bagi orang-orang yang menggeluti isu pencemaran udara, tapi siapa pun yang senang dengan cerita perjalanan menuju perubahan. 


\section{Tentang Penulis}

Richard L. Revesz lulus dengan predikat summa cum laude dari Princeton University, memeroleh gelar master di bidang Teknik lingkungan dari Massachusetts Institute of Technology, dan menerima gelar hukum dari Yale Law School, di mana dia menjadi pemimpin redaksi the Yale Law Journal. Selain menjadi pengajar di New York University School of Law, Revesz menjadi profesor tamu di Princeton's Woodrow Wilson School of Public and International Affairs, Harvard Law School, Yale Law School, dan the Graduate Institute for International Studies di Geneva, Swiss. Revesz telah menulis delapan buku dan lebih dari 70 artikel di jurnal-jurnal hukum besar.

Jack Lienke mendapatkan gelar Bachelor of Arts (B.A.) dari Vassar College dan gelar Jurist Doctor (J.D.) cum laude dari New York University School of Law. Selain menjadi Policy Regulatory Director di Institute for Policy Integrity, Lienke juga menjadi asisten profesor di New York University School of Law, di mana dia mengajar Klinik Peraturan Kebijakan. Lienke menulis banyak opini di media seperti The New York Times, The Washington Post, Salon, Mother Jones, dan Grist. Dia juga menulis banyak pendapat untuk pengadilan dalam berbagai kasus lingkungan hidup di Amerika Serikat. 